\title{
Article
}

Lee Wilson*

\section{Why They Know Not What They Do: A Social Constructionist Approach to the Explanatory Problem of False Consciousness}

https://doi.org/10.1515/jso-2020-0012

Published online June 21, 2021

\begin{abstract}
False consciousness requires a general explanation for why, and how, oppressed individuals believe propositions against, as opposed to aligned with, their own well-being in virtue of their oppressed status. This involves four explanatory desiderata: belief acquisition, content prevalence, limitation, and systematicity. A social constructionist approach satisfies these by understanding the concept of false consciousness as regulating social research rather than as determining the exact mechanisms for all instances: the concept attunes us to a complex of mechanisms conducing oppressed individuals to mistake social understandings of themselves as natural self-understandings-the limits lie where these overlap, or are entirely absent.
\end{abstract}

Keywords: false consciousness, social philosophy, epistemic oppression, ideology, critical social ontology

Women pundits like Ann Coulter and Janet Bloomfield consistently argue that women's suffrage was a mistake and that women today should be disenfranchised. They claim that women "have had the vote in the West for almost 100 years, and all they have done is vote to destroy and destabilize the world men built for us" (Bloomfield 2017). Their arguments echo those of women antisuffragists in Victorian Britain, who campaigned against suffrage on the basis that "the necessary and normal experience of women [...] do[es] not and can never provide them with such materials for sound [political] judgement as are open to men." (“An Appeal” 1889, p. 782). Such cases are baffling at first glance, for they involve agents systematically regarding themselves as prudentially or morally justified in acting in ways that contribute to their own oppression.

*Corresponding author: Lee Wilson, Philosophy, University of Edinburgh School of Philosophy Psychology and Language Sciences, Dugald Stewart Building, 3 Charles Street, Edinburgh EH8 9AD, UK, E-mail: lee.w@ed.ac.uk. https://orcid.org/0000-0002-1785-2723 
In response, social philosophers often invoke the traditionally Marxist notion of false consciousness in their particular analyses of such phenomena. 'Falseness' here is understood as threefold: epistemically, functionally, and genetically (Geuss 1981; Shelby 2003). That is, false consciousness is a set of ignorant beliefs, functioning to motivate actions that would perpetuate structural oppression, and caused by epistemic practices adversely conditioned by structural oppression. While this may also include a belief that $p$, where $p$ is true, this is still understood as ignorant here insofar as it falls short of knowledge: the belief would still be held if $p$ were false and it is based on unreliable belief-forming processes. ${ }^{1}$

However, the concept of false consciousness is often denigrated as suffering from several problems. The first is explanatory: the concept is seen as lacking an adequate general theory and bottoming out as an ad hoc explanation for particular behaviour. The second is normative: the concept is seen as imposing evaluative standards that are foreign to the agents being criticised. The third is epistemological: where the relevant evaluative standards are epistemically inaccessible to even the critic. And the fourth is agential: the use of the concept is seen as implicitly supporting, if not amounting to, victim-blaming. These problems must be addressed if the concept of false consciousness is to perform the diagnostic work that social philosophers want for it to do in their analyses of structural oppression (cf. Celikates 2017). In this paper, I focus on the first and most fundamental of these: the explanatory problem.

The explanatory problem of false consciousness is the lack of a satisfactory standard explanation for how individual cognition and social schemas generally interact in (sometimes overlapping) oppressive practices, such that agents systematically believe propositions against their own well-being. First, past attempts to address this problem by the Analytical Marxists (G. A. Cohen, Jon Elster) have been found to be either ontologically excessive, positing a selfmaintaining entity over and above individuals, or excessively individualistic, being too focused on individual psychology to reveal anything informative about structural oppression (Rosen 1996). As such, the concept is generally deemed to be theoretically ill-suited for systematic research and emancipatory praxis beyond particular, one-off cases. Second, more recent attempts tended to only focus on static, seemingly self-contained, singular types of oppressive schemas. But a general theory has to account for how dynamic and overlapping types of oppression affect agents at their junctions differently (cf. Ásta 2019; Curry 2014). It is crucial to recognise both the theoretical inseparability of identity categories (for example, 'Black man') and the various injustices that are occasioned by onesided analyses. False consciousnesses may conflict in cases where structures of

1 In other words, such beliefs are both epistemically insensitive and unsafe. 
oppression overlap differently. Overlooking such conflicts means overlooking the specific epistemic and moral harms suffered by such agents.

To address these concerns, I propose a social constructionist approach here to the explanatory problem as an exercise in critical social ontology (cf. Renault 2016). The approach brings together social construction and critical theory to better satisfy the theoretical and emancipatory requirements of social analyses hitherto overlooked in previous approaches-especially in cases of overlapping oppression. Following recent directions taken by social constructionists like Sally Haslanger, I draw on Louis Althusser's discussion of ideology in On the Reproduction of Capitalism to understand the concept of false consciousness as allowing us to attend to the various stabilising mechanisms in structural oppression that conduce the oppressed to mistake socially constructed understandings of themselves as natural self-understandings. ${ }^{2}$

In what follows, I first consider the relation between ideology and false consciousness, motivating the need for a theory of false consciousness independent of the theory of ideology (\$1). I then lay out the explanatory desiderata that any such theory is required to satisfy for social critique (\$2). I evaluate three theoretical approaches against how they satisfy these desiderata-approaches taken as providing explanations for false consciousness in analytic social philosophy (\$3): functionalism, which explains it in terms of its overall societal function; psychologism, which explains it in terms of oppressed individuals' psychological failures; and processualism, which explains it in terms of the oppressed's epistemic deference to oppressors. While these are shown to be inadequate for satisfying the desiderata on their own as opposed to the social constructionist approach, I ultimately suggest that they can all be subsumed under the latter (§4). In doing so, I return constantly to the case of women antisuffragists-particularly Mary Augusta Ward, the founding president of the Women's National Antisuffrage League-as a relatively uncontroversial instance of false consciousness. However, I also draw from a wide range of oppressive contexts, since what we require is a general theory instead one specific to women antisuffragists.

It should be underscored that social constructionism is not meant to be a new approach as particular accounts of false consciousness go: historical precedents include Hume's Natural History of Religion, José Rizal's The Indolence of the Filipino, and Beauvoir's The Second Sex. What is advanced here, rather, is a general approach to theorising about false consciousness that meets the explanatory desiderata needed by the social philosopher, regardless of the

2 Haslanger would herself be hesitant to use the language of 'false consciousness' out of an unwarranted (as will be shown) fear of the methodologically individualist cognitivism it connotes (Haslanger 2017a, p. 9 note 8). 
type(s) of oppression analysed. ${ }^{3}$ Resolving the explanatory problem would thus be a fundamental step towards rehabilitating the concept of false consciousness as a whole, on the basis of which the normative, epistemological and agential problems may be addressed elsewhere.

\section{Ideology and False Consciousness}

As a critical concept, false consciousness is not merely meant to draw attention to neglected oppressive aspects of an otherwise seemingly benign social structure. In doing so, it is also meant to orient us towards amelioration or emancipation. This is because, as foregrounded in the Marxian traditions and related critical theories, the concept is bound up with the concept of ideology-so much so that the terms 'false consciousness' and 'ideological consciousness' are often used interchangeably in the case of the oppressed. ${ }^{4}$ Such theorists generally take 'ideology' to refer to a schema of "public meanings, scripts, etc." that serves in some way to undergird, and also arises out of, problematic social practices (Haslanger 2019, p. 5). ${ }^{5}$ Generally, agents, oppressed or otherwise, are under schemas that confer upon them a range of constraints and enablements salient for action-guidance. Given this, we can say that a social structure consists of a network of practices involving resources (such as tools and materials) and agents, organised by schemas (Haslanger 2011). These schemas are usually taken for granted, left in the background and unthematised, such that they seem to be 'just the way things are'. Allowing us to thematise, problematise, and reorient, our consideration of social practices is precisely what the concept of ideology is meant to do: that we would be able to identify problems in schemas that manifest in particular social practices. For instance, British suffragists drew on some tacit theory of ideology when they campaigned against the gender inequality manifest in asymmetrical marital laws

3 In Althusser's words, what we are concerned with is "the project of a theory of ideology in general, as opposed to a theory of particular ideologies, considered either with respect to their regional contents (religious, moral, legal, or political ideology, and so on) or class orientation (bourgeois, petty-bourgeois, proletarian ideology, and so on)" (Althusser 2014, 174).

4 The ideological consciousness of oppressors, although also of considerable importance and would no doubt relate to the greater amount of recent discussion on systematic ignorance of oppressors, will not be considered here.

5 Recent reflections on the concept of ideology disambiguate between two senses of the term as employed historically: general or pejorative (Celikates 2017; Haslanger 2014). The general (or nonevaluative) sense remains agnostic about the problematic nature of the social practices undergirded by ideology; whereas the pejorative (or evaluative) sense has that the social practices are problematic. The latter sense is used here, leaving aside concerns about how 'problematic' is to be determined (i.e. the normative and epistemological problems). 
and parliamentary exclusion. Such practices, they argued, were for a long time organised around the principle that "it is the duty of women, [...] that it is their nature, to live for others; to make complete abnegation of themselves, and to have no life but in their affections [...] to the men with whom they are connected, or to the children who constitute an additional and indefeasible tie between them and a man" (Mill 1995, p. 132-133).

There are, of course, recidivistic beliefs that arise out of delusions, selfdeception, epistemic vice, or implicit bias. But false consciousness cannot be understood as delusions, insofar as the latter involve beliefs of ordinarily irrational agents; as self-deception, insofar as this does not capture the systematicity of beliefs that contribute to structural oppression; as epistemic vice, insofar as such beliefs are not required to be formed in virtue of an agent's position in structures of oppression; and as implicit bias, insofar as this involves attitudes that are directly inaccessible to consciousness. Admittedly, however, there is a trend that defines 'false consciousness' independently of ideology: as being merely ignorant of the reasons for which an agent holds onto a given set of beliefs, sometimes aligning it with a Sartrean notion of bad faith (Barnes 1997; Shelby 2014). Taking their cue from Engels' 1893 Letter to Mehring, some philosophers decouple the concept of false consciousness from the concept of ideology and its structural implications, holding that the former is a cognitive matter of misunderstanding the motives of one's beliefs. Such beliefs are thought to be held rationally when they are really held irrationally. Exegetical issues aside, this is unhelpfully vague. Such a characterisation could apply to a wide range of beliefs that we would not ordinarily regard as problematic, even if they were held recidivistically. For example, "that I have hands, that $2+2=4$, that my mother loves me" (Srinivasan 2016, p. 374). As such, it would be more than prudent to take 'false consciousness' to refer to a recidivistic set of ignorant beliefs held by oppressed agents under ideology. ${ }^{6}$

Despite their conceptual intimacy, it is crucial to distinguish between questions concerning ideology and those concerning false consciousness. A focus on ideology is more concerned with problematic representations in relation to structures as a whole. But a focus on false consciousness is more concerned with the formation and maintenance of these problematic representations in relation to the lived experiences of agents in these structures. Such explicit focus on how and why oppressed agents at these structural nodes "effectively confer from the bottom

6 There are, of course, non-doxastic forms of false consciousness: perceptual, emotional, etc. (Rosen 1996). While some or all of these may no doubt overlap in various cases, I focus here only on doxastic false consciousness, given that most users of the concepts of false consciousness and ideology largely understand them to minimally involve beliefs (see Jaeggi 2009; Meyerson 1991; Stanley 2015). 
up the relations of subordination that affect their lives" is relatively lacking (Thompson 2013, p. 185). But this focus is essential for critique. The concept of false consciousness attends to that which a focus on ideology alone overlooks: one's capacity for self-knowledge qua agent. Agents, after all, may be located at junctions of overlapping structures of oppression, thereby developing belief-sets involving multiple ideologies (cf. Crenshaw 1991; Hutchinson 2001).

A 'bottom up' approach, on the one hand, better attends to how overlapping structures of oppression and ideologies present distinct-not just additive-instances of false consciousness that can also be dynamic and interactive. A theory of ideology alone is ill-suited for this task. To illustrate this, consider how the women antisuffragists' widely circulated justifications for rejecting the vote reflected their varied social positions, where gender oppression overlapped with economic oppression. ${ }^{7}$ Both Ward, who was a then millionaire-equivalent, and Maud Ellen Simkins, a wage-labourer, shared the ignorant belief that "women are domestic creatures" by nature and can never be political ones (Simkins 1909a, p. 14). Yet, for Ward, 'domestic' activities included "care of the sick and the insane; the treatment of the poor; the education of children", confined by national borders ("An Appeal" 1889, p. 782). While, for Simkins, 'domesticity' was restricted to the upkeep of the household. Ward campaigned against suffrage for reasons such as the superfluity of the vote partly since "all the principal injustices of the law towards women have been amended by means of the existing constitutional machinery" ("An Appeal” 1889, p. 787). Conversely, Simkins publicly opposed suffrage because it would disproportionally affect women workers like herself, who would be saddled with "the triple burden of wage-earning, housekeeping, and political responsibility", believing that the initial double burden of wage-earning and housekeeping was "because the wealthier women have been neglecting the first elementary duties of women that the poor have come to [squalor and discomfort]" (Simkins 1909b, p. 790-793). Both Ward and Simkins' false consciousnesses did not result from just adding patriarchal and bourgeois ideologies together-there is mutual reinforcement between these ideologies in each specific junction, presenting unique types of oppression and corollary false consciousnesses depending on the overlap. Our understanding of how patriarchal ideology worked in Britain thus cannot just involve a 'top down' accommodation of these diverging sets of beliefs. While both sets of beliefs might follow from the principle of feminine self-abnegation, this alone is insufficient to account for the conflict between them.

On the other hand, the need for 'bottom up' analyses also arises from a growing trend that approaches emancipation in terms of the possibility of collectivising

7 Also, colonial oppression: much of the discourse also concerned "Imperial responsibilities" (Ward 1918, p. 58). 
epistemic resistance among the oppressed and their own responsibility to resist and challenge structural oppression (Goodin and Spiekermann 2015). This is because, as standpoint theorists and epistemologists of resistance are keen to emphasize, "any account seeking to remedy structural injustice in ignorance of the standpoint of the oppressed would be both paternalistic and more likely to err", even reinforcing the oppressive relations (Jugov and Ypi 2019, p. 11). If the goal of critique is to conduce the emancipation of the oppressed, for them to overcome their alienation in the social world and in relation to themselves, it must not only attend to the problems of ideology but also attend to how exactly individual epistemic agencies might be restored. ${ }^{8}$ The concern here is thus not just the content of a given ideology and how it manifests in social practices, but also the processes rendering an agent's lived ideological experience 'natural' and how they might be avoided or overcome.

\section{Explanatory Desiderata}

In setting out a general theory of false consciousness, we must first clarify the necessary and sufficient conditions for any explanation of any instance of the phenomenon. I will now lay out the explanatory desiderata that such a theory must satisfy, along with why and how it should do this. An adequate explanation for any instance of false consciousness must satisfy the following:

Acquisition: How affected oppressed agents come to form and maintain certain ignorant beliefs as (putative) knowledge.

Content: How the content of such beliefs are formed and maintained in the structural ambits within which such agents are embedded;

Scope: How other oppressed agents may nevertheless avoid, or even resist, forming or maintaining such beliefs.

Any explanation of false consciousness must not only attend to the processes resulting in the acquisition of ignorant beliefs at the individual level in a way that resists counter-evidence (Acquisition) but also processes that promote ignorant content at the structural level (Content). And given the ameliorative aim of critique, resistant epistemologies among oppressed groups, and how infrequently we notice false consciousness among the oppressed, such an explanation must also involve accounting for how an absence of false consciousness is nevertheless possible despite these processes (Scope).

8 For more on the notion of ideology critique, see Jaeggi 2009; Shelby 2003. 
Moreover, there is a 'meta-requirement' for any explanation for false consciousness:

Systematicity: An account of false consciousness must explain the previous three desiderata as a systematic unity.

In a systematic unity, components are interconnected in a manner grounded by a single principle to form a whole. Within the context of social critique, the limited acquisition and content of false consciousness should be identifiable as belonging to a social structure (or overlapping structures). ${ }^{9}$ This would mean being able to map out mutually implicating beliefs within a particular oppressive schema (or schemas), allowing us to characterize them as ideological and needing amelioration. For example, an explanation of a belief-set involving 'women are naturally deficient in political deliberation' or 'women should be married' would be interconnected within the patriarchal schema of Victorian Britain's social structure, grounded by the aforementioned principle of feminine self-abnegation. Whereas a belief like 'women inhabit the second planet from the Sun' might be connected with the previous beliefs by the principle ' $x$ pertains to women', but it is neither mutually implicating nor relevant for social critique. ${ }^{10}$

There cannot be any social critique with explanatory patchworks that satisfy all three conditions but have them obtaining together only by sheer happenstance. That is, it is not enough to just say that Acquisition and Content often coincidentally operate together and that Scope can be explained insofar as such operations are absent. To illustrate this, consider the particular case of Ward's false consciousness: ${ }^{11}$

ANTISUFFRAGist: Mary Ward has the ignorant beliefs that women are naturally deficient at political deliberation and that suffrage is unnecessary for addressing injustices specific to women [epistemic 'falsity']. These beliefs motivate her to pen and publish the influential manifesto, "An Appeal Against Female Suffrage" [functional 'falsity']. Ward has these beliefs owing to a general absence of women in Victorian politics and also her being unfamiliar with how legislative practices more than education still constrained working-class women thus far [genetic 'falsity'].

A possible (fictional) patchwork explanation for this, satisfying all the explanatory desiderata but Systematicity, might be:

9 cf. Hannah Arendt's understanding of ideology as "quite literally what its name indicates: it is the 'logic of an idea'” (Arendt 1976, 469).

10 I would like to thank an anonymous reviewer pushing me to clarify this issue and for the inspiration for how to do so.

11 The choice to focus on Ward's case over Simkins' is also due to the former's beliefs being better documented over time-whether through her political publications, novels, memoir, or personal correspondences-throughout the antisuffrage campaigns. 


\begin{abstract}
EXPLANATION $_{\mathrm{Pa}}$ : Ward has these beliefs because, as a child, she picked up a note in school stating that 'women are naturally deficient in political deliberation' and that 'suffrage is unnecessary for addressing injustices specific to women'. She had no opinion on the matter before this encounter because these were not in the school's curriculum; she maintains them because her childhood memories of school became sacrosanct for her in face of rapid urbanisation [Acquisition]. The note was in the school because someone scribbled it in a sudden religious epiphany and it is maintained because everyone who picked up the note just tosses it on the ground again [Content]. And those who did not attend the school did not pick up the note, thereby not forming and subsequently maintaining the beliefs [Scope].
\end{abstract}

It is clear from this that, even if ExPLANATION $_{\mathrm{Pa}}$ were true, it would fall short of the social philosopher's aim of bringing one's attention to the processes that systematically operated among similar antisuffragists: the explanation, while it might be satisfactory for explaining ANTISUFFRAGIST in the context of such a biography, is irrelevant to structural oppression, as the details attended to do not highlight structural factors that contribute to the epistemic, functional, and genetic 'falsity' of her beliefs. For example, the reason for her school's curriculum design, the reason for the epiphany's antisuffragist content, or the reason why suffragists were not generally in her school. EXPLANATION $P a$ could also apply to someone like Simkins in a way that provides no insight into how Ward's bourgeois position is related to her position under patriarchy. It also does not account for how her beliefs and actions converged with the other bourgeois antisuffragists. Over 420,000 mainly upper- and middle-class women signed an antisuffrage parliamentary petition organised by the Women's National Antisuffrage League. And modern historians gather that most working-class women then "had little interest in the vote before the war, and only limited interest once it had been finally placed in [their hands]" (Bush 2007, p. 189, 311). How Acquisition and Content are related in the cases of these two classes of women antisuffragists, and how their cases are related to each other, thus cannot be a matter of mere statistical coincidence. Such operations were not just regular but schematic: affected agents regularly accept or reject evidence according to these schemas governing false consciousnesses. For a theory of false consciousness to contribute to the diagnostic and ameliorative tasks of critique, it must therefore show how these sets of beliefs are interconnected within ideologies of structures of oppression.

Furthermore, for an explanation to be critical, it is expected to also involve Scope systematically for at least two reasons. First, social philosophers often hold that motivating and normative reasons for ideological resistance are already implicit in, and particular to, a given instance of ideology (Jaeggi 2019). The content of these reasons are to arise from analyses of the corresponding social structure, instead of it being just a matter of applying universal epistemological or moral criteria in evaluating the ideology. Second, irrespective of this, if we hold 
that emancipatory hope is to be found largely in solidarity among the oppressed, we need to account for how such cases diverge for the sake of differential emancipatory strategies. This was reflected in the suffragist arguments directed to women, which had varying degrees of efficacy depending on their audience's class: they emphasised how extending suffrage would ameliorate working-class conditions and how many upper- and middle-class women already had one foot in politics via organisations like the Primrose League.

\section{Survey of Extant Approaches}

Functionalism, psychologism, and processualism are seen as candidate approaches to answering the explanatory problem. Criticisms of functionalist and psychologistic approaches specific to the concept of ideology have had a long run since the heyday of Analytical Marxism in the 80s (see Rosen 1996). Instead of revisiting them, I only focus here on how these approaches, alongside processualism, fail to fully satisfy the desiderata for an adequate explanation of false consciousness.

\subsection{Functionalism}

Functionalism is an approach to explaining false consciousness, and ideology more broadly, that is often associated with the controversial ontological assumption that society is a distinct entity that maintains itself through the false consciousness of members of its constituent social groups (Cohen 2001; Shelby 2003). ${ }^{12}$ Still, the reifying assumption is unnecessary. What is crucial to this approach, as paradigmatically put forward by Cohen, is that false consciousness is functionally explained by the maintenance of the social arrangement of a society that is stratified across oppressive lines. By 'functional explanation', the functionalist means that the function of an attribute of an object is cited as an explanation of the object having it-akin to the kinds of explanations that are found in the natural sciences. For example, to explain the melanism of peppered moths, it would be sufficient to cite melanism's function of promoting species survival. This is not because it directly explains the attribute possession but because giving the statement ' $A$ is functional for $B$ ' as an explanation is adequate as a working hypothesis for why a particular object is $A$, without yet needing to provide an underlying, elaborating mechanism (like natural selection, in the peppered moths

12 The approach mainly arose out of attempts by Analytical Marxists-specifically, Cohen-to not only provide a scientific basis for the theory of ideology but also maintain as much fidelity to Marx's works as possible. 
example). Functionalists thus think it sufficiently explanatory for false consciousness to cite its function of maintaining a given oppressive society.

The functionalist would explain ANTISUFFRAGIST as follows:

EXPLANATION $_{F N}$ : Ward has the ignorant beliefs that women are naturally deficient at political deliberation and that suffrage is unnecessary for addressing injustices specific to women, motivating her to campaign against women's suffrage, because this is functional for the patriarchal and bourgeois organisation of Victorian Britain.

EXPLANATION $_{F N}$ seems to be able to secure Content: the oppressive content of the ideas (that 'women are naturally deficient at political deliberation') would be explained as those content that conduce the maintenance of an oppressive society (keeping women out of politics). It also secures Systematicity: the relation of Content to the social structure is purportedly secured by the principle of societal self-maintenance.

There is, however, no concern for Acquisition and Scope: no account is provided for the mechanisms that lead Ward to acquire the relevant ignorant beliefs given her position in gender and economic oppression, nor is there any account of why there should be oppressed agents, like working-class suffragists, who systematically avoid false consciousness. Further, the explanations for Content and Systematicity can only be partial, since EXPLANATION ${ }_{F N}$ does not account for why there should be a difference between the content of Ward and Simkins' belief-sets. In considering the overlap of gender and economic oppression, both their false consciousnesses are simply 'functional for the patriarchal and bourgeois organisation of Victorian Britain'.

It is unclear then, how much EXPLANATION $_{F N}$ is an explanation for false consciousness so much as a restatement of the explanatory problem, like citing the virtus dormitiva of opium as an explanation for it causing sleep. That is, that false consciousness occurs because it sustains a given oppressive society is uninformative for the general project set out here: it is in fact just rehashing the functional 'falsity' in the definition of the concept as an explanation. This is because a functional explanation is, after all, meant as a hypothetical explanation that would guide particular social research into underlying mechanisms (Cohen 1982; Paprzycka 1998). At the level of abstraction we require, it is ill-suited for satisfying the explanatory desiderata.

\subsection{Psychologism}

'Psychologism' refers to various approaches that attempt to explain false consciousness by psychological mechanisms at the individual level, coming out of 
trends in social psychology to treat structural failures as fundamentally individual failures. These mechanisms that compromise one's epistemic capacities range from adaptive preferences, where ignorant beliefs are indirectly acquired and maintained through an adjustment of the preferability of an initially preferable object (Elster 1983); the just-world hypothesis, where in virtue of one's bias that the world is just, oppression is understood as just retribution (Lerner 1980); to aliefs, which are automatic proto-doxastic responses to stimuli (Gendler 2011). Further, many note that the recidivism of false consciousness occurs not just in virtue of an agent's group membership in such a structure but also in virtue of their selfidentification as a group member (Cudd 2006; Meyerson 1991). Roughly, the maintenance of the relevant ignorant beliefs is motivated by a desire to avoid the truth about a given proposition, where this desire is generated by an agent's higher-order desire to understand themselves as a certain kind of (efficacious and competent) moral agent and where this self-understanding is in turn derived from their membership in a social group.

A psychologistic explanation of ANTISUFFRAGIST would be:

EXPLANATION $_{p s}$ : Ward has the ignorant beliefs that women are naturally deficient at political deliberation and that suffrage is unnecessary for addressing injustices, motivating her to campaign against women's suffrage, which is formed and maintained owing to psychological mechanisms that inhibit her ability to appropriately respond to suffragist reasons.

The variety of mechanisms identified by those who adopt this approach ensures that Acquisition would be satisfied. However, on its own, EXPLANATION ${ }_{p s}$ cannot satisfy Content, Scope, and Systematicity. As Michael Rosen observes, a focus on content-insensitive failures of individual psychology is inadequate for why the content of the ignorant beliefs that are accepted and maintained through these mechanisms are the kind that support structural oppression (Rosen 1996): the question remains as to why 'women are naturally deficient at political deliberation' should be the content of Ward's belief in psychological failure, instead of 'women have equal capacity for political deliberation'. Further, why these failures do or do not occur (and continually so) in a systematic way remains unaddressed. Unsurprisingly, explicit attempts to explain false consciousness with psychologism do so by hybridising the approach with functionalism (Meyerson 1991), historicism (Elster 1982), or processualism (Shelby 2003).

These hybrid approaches are nevertheless inadequate for critique. Psychologismfunctionalism and -processualism hybrids (as we will see) would still fail to account for Scope and at least Systematicity, since no explanation is provided for systematic resistance (like why such mechanisms are not also in operation for suffragists). And while a psychologism-historicism hybrid, wherein psychological mechanisms are contextualised within historically specific social practices 
(like the asymmetrical upbringing and education of Victorian women), may well account for Acquisition, Content, and Scope in particular cases of false consciousness, it remains too uninformative for our concern here for a general theory-failing Systematicity.

\subsection{Processualism}

Processualism is gaining attention recently due to ongoing work on epistemic oppression (pioneered by Kristie Dotson), drawing on Antonio Gramsci's understanding of the concept of ideology as cultural hegemony (Medina 2013; Mills 2017). The approach attempts to explain false consciousness by articulating the epistemological implications of the hegemonic relations between the oppressing group and the oppressed. That is, instead of understanding individual epistemic failure among the oppressed to be fundamentally explanatory as is the case in psychologism, processualism understands epistemic failure to be a relational failure. That is, processualism approaches false consciousness as a result of an active exclusion of the oppressed from participating in the larger epistemic community by the oppressing group at various orders (Dotson 2014). As such, the oppressed have deflated credibility with regard to themselves and epistemically defer to an credibility-inflated oppressing group with respect to the relevant ignorant beliefs.

According to the most recent and detailed processualist account by Jason Stanley (2015), it is because the oppressed are regularly placed in high-stakes situations (due to less material security) that they lose knowledge. That is, as a result of pragmatic encroachment (whether in virtue of interest-relativity or confidence-shaking), self-confidence in oneself as an epistemic agent decreases. And given the epistemic advantage afforded by their material advantage, members of the oppressing group overextend epistemic and practical authority over to claims pertaining to the oppressed. Consequently, the oppressed defer to the oppressing group's claims, which are systematically detrimental because their content derive from legitimation myths developed by the oppressing groups. Such myths arise out of the latter's desire to preserve the material inequality from which they benefit (like through propaganda).

The processualist would explain ANTISUFFRAGIST as follows:

EXPLANATION $_{p}$ : Ward has the ignorant beliefs that women are naturally deficient at political deliberation and that suffrage is unnecessary for addressing injustices, motivating her to campaign against women's suffrage, due to her deference to the epistemic authority of men, who propagate the myth of the political inaptitude of women to maintain their position in the gender hierarchy. 
In this way, EXPLANATION Content with legitimation myths, and Systematicity with how these relational practices presuppose the hegemonic organisation of social groups.

However, this account is unable to account for Scope in all instances of false consciousness. Amia Srinivasan illustrates this with the case of a woman whom we would say does retain knowledge that she was sexually harassed, despite being in a high-stakes situation like taking legal action against her boss for the act and despite the "scepticism or gaslighting she encounters", such that "she continues to act rationally when she pursues her protest" (Srinivasan 2016, p. 378). ${ }^{13}$ Some address of this might be found in the idea of practices where oppressed agents direct their "epistemic energy toward and in connection with other nondominantly situated subjects", attending to affinities and distinctions among them (Pohlhaus Jr. 2020, 245). These would accordingly form new relations and alliances independent of oppressors and illuminate "how epistemic systems function in the non-ideal world" (cf. Medina 2013; Pohlhaus Jr. 2020, 247). However, the idea of such practices does not suffice for how some of the oppressed avoid false consciousness to begin with.

Yet even if this could address Scope, under any processualist approach, Content is not always satisfied. A conspiratorial account of the oppressing group is not always plausible. It is often the case that the maintenance of legitimation myths is unintentional (perhaps as a matter of ideological consciousness in the oppressed) or even only tacit in practice (like implicit bias). Especially for myths maintained by the same group across long time scales, such deception would require an accurate grasp of the actual state of affairs, which is not only unnecessary for propagating these myths but also largely unempirical (Shelby 2003). Admittedly, it may be the case that legitimation myths are sometimes initially formed by a select portion of the oppressing group intentionally seeking to preserve their material inequality. But the crucial point is that it would be implausible to see this in all occasions of false consciousness. It seems more plausible and common that many legitimation myths that supposedly reinforce structural oppression are not perniciously created. Examples of this include the notions of meritocracy and racial colour-blindness. While these notions may have since been used to legitimise certain structures of oppression, this does not imply that their formation were similarly motivated: meritocracy has its earliest, and most influential, articulations in Plato's Republic and Confucius' Analects; and racial colourblindness in the US civil rights movement.

13 The account itself might thus be said to enact an overextension of epistemic and practical authority (stoking fears of paternalism). 
Further, the necessary material basis of this approach cannot accommodate the persistence of cases of false consciousness when there is material equality between groups. We see this in cases of 'Pinkerton Syndrome', where Singaporean Chinese would tend to provide preferential treatment for White people (Chew/ Young/Tan 2019). And more generally, processualism alone is still insufficient to account for the positive internalisation of the relevant content by some significant portion of the oppressed, especially among those that further produce highly abstract and nuanced constituent elaborations of the ignorant beliefs. Women antisuffragists were at the forefront of the Victorian literati. It is not clear why they should not just be defeatists, sceptics, or ironists about such beliefs. Both these explanatory gaps apply to EXPLANATION ${ }_{\text {pr }}$. Systematicity and Acquisition thus do not fully obtain under processualism either.

\section{Social Constructionism}

The above approaches to false consciousness are, however, not necessarily in direct tension with each other. Instead of displacing them, the social constructionist approach may perhaps be seen as grounding a hybridisation of all three. In this section, I develop such an approach based on Althusser's analysis of ideology that meets all the explanatory desiderata. Althusser's analysis of ideology differs from Gramsci's insofar as the focus is on an agent's consciousness as structured rather than structural hegemony. ${ }^{14}$ Specifically, Althusser understands ideology (or schemas, more generally) as a three-part system that involves the "interpellation of individuals as subjects", "mutual recognition between subjects and Subject and among subjects themselves, as well as the recognition of the subject by himself", and "the absolute guarantee that everything really is so" for the subject (Althusser 2014, p. 197). That is, ideology hails an individual as such-and-such a participant in its structure, within which they are affirmed and affirm themselves as such a participant, and this state of affairs is naturalised. I conclude by considering how functionalism, psychologism, and processualism are subsumed and supplemented by social constructionism.

14 For consistency, Althusser's own notion of 'ideology' is simply referred to as 'schema' here, as he uses the term in a neutral way that also applies to unproblematic practices. For example, he refers to revolutionary organisations as operating on "proletarian ideology" (Althusser 2014, p. 181). 


\subsection{Interpellation}

The 'interpellation of individuals as subjects' is a constitutive process by which an individual becomes a kind of subject under a representational schema. In other words, social properties are constructed upon a base property (aspects of the individual human being) to create a subject (an interpellated individual). Whether under constitutional (Searle 2010), response-dependent (Pettit 1991) or conferralist frameworks (Ásta 2018), social construction minimally involves a joint acceptance condition:

members of a group individually accept facts $F$ about object $O$ and there is mutual knowledge that other members accept $F$.

That is, kinds of objects are socially constructed when the kind of object comes to possess certain social property, where such a property arises out of a joint acceptance (that a kind of object $O$ is $F$ ) by members of a group of people whether at the level of formal institutions or informal communities.

Crucially for interpellation, groups of people-that is, members within themare also constructed as subjects, insofar as they have properties jointly accepted of them within a network of social practices. For example, an intersex individual born with both ovarian and testicular tissues would be assigned exclusively either female or male by most medical institutions. These interpellating social categories and corollary properties come with, if not just are, constraints and enablements within social contexts that would have significant effects on the attitudes and behaviours of individuals. That is, individuals are interpellated as subjects insofar as they are always already constructed under some schema that relate them in social practices-as schematised objects-to other resources, other schematised agents, and to themselves. Such schematisation is a precondition of being considered a participant in a given social practice.

Importantly, apart from institutional regulation like incarceration or even the threat of negative communal sanctions (which both apply to the alreadyconstituted subject), Althusser notes a "[strange] obligation to respond to every hailing [by interpellation]": an underlying norm for an individual to acknowledge themselves as being addressed by the social schemas they find themselves in (Althusser 2014, p. 191). ${ }^{15}$ This norm of acknowledging 'being a subject who is

15 That is, irrespective of repressive state apparatuses like police or military intervention; or what Searle calls "background power", i.e. the "set of presuppositions, attitudes, dispositions, capacities, and practices of any community that set normative constraints on the members of that community in such a way that violations of those constraints are subject to the negative imposition of sanctions by any member of the community" (Searle 2010, p. 160). 
addressed as such-and-such' asserts a pressure on individuals to participate in joint acceptances whose source is thus neither institutional nor communal but simply an individual's receptivity to sociality-even if they do not subsequently recognise themselves in the schema or only do so in defeatism, scepticism, or irony. Non-binary individuals, for example, still acknowledge binary gender schemas as at least addressing them-albeit problematically. Therefore, the normative force of joint acceptances is not found merely coming from the confines of the oppressed group (cf. Thompson 2017). Both oppressing and oppressed groups partake in the same, wider social structure and ideology, within which they partake in the joint acceptance of themselves as instantiating certain social facts particular to the groups they belong to.

So while schemas may be found to be functionally problematic in critique, the constructive acts that give rise to certain attitudes and self-understandings that support structural oppression need not be-that is, both the initial positing of an object as possessing certain facts and the subsequent joint acceptances. Pace conspiratorial accounts, constructive acts may also just be defective or unwitting, with the effect of the oppressive relation resulting unintentionally.

\subsection{Recognition}

As a result of interpellation, a subject is able to have standing under a schema or ideology-be recognised-with respect to the social world, other subjects, and, most importantly for the concept of false consciousness, oneself. That is, a subject acquires social standing within a network of practices, within which they are related to -reinforcing joint acceptance-as such-and-such a subject, whether practically (in sexual harassment) or representationally (in TV scripts). And this forms the basis of their self-recognition and hence self-understanding. This is what Ian Hacking (1995) observes as 'the looping effect', feedback loops between social classifications and how the classified understand themselves and behave (Figure 1):

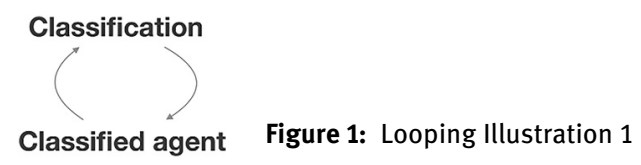

That this feedback loop occurs might be said to be simply a feature of our cognition in general. Seen from the predictive processing paradigm, cognition aims to track the world by modelling sensory input with generative models, which "capture the statistical structure of some set of observed inputs by inferring a 
causal matrix able to give rise to that very structure" (Clark 2015, p. 21). Our cognition not only models objects and their relationship to each other but also agents-including, crucially, our selves. Unlike cognitions of objects and other agents, which involve causes that pertain to sensory data coming from outside the body, our self-cognition involves modelling endogenous causes (Seth, Suzuki, and Critchley 2012). Such self-cognition begins in infancy, when we start to apply the 'agent-models' generated prior, and the agent-models ascribed to us, to understand the endogenous sensory input of the body as caused by such-and-such an agent-on the basis of which we then act accordingly, confirming the ascriptions (Hohwy and Michael 2017). Such application of agent-models continues into adulthood. This is thus how interpellation is internalised and one recognizes oneself as such-and-such a subject under a given schema: in this feedback loop between the agent and the ascribed classification, the corollary social properties and schemas are more than jointly accepted of a classification-they become one's own properties and self-understanding. ${ }^{16}$

Pertinent to false consciousness is how such a complex of feedback loops leads to certain joint acceptances taking precedence over others. We need to attend to how, in cases of structural oppression, certain looping mechanisms systematically function to promote specific ignorant beliefs in spite of counter-evidence. That is, we are concerned with how the concept can guide attention to what these epistemically unresponsive mechanisms are, as well as how they work to naturalise ideological experience of the social world such that beliefs pertaining to these social objectifications, and not others, are 'guaranteed'-that is, taken for granted as (putative) knowledge in the agent's lived experience.

\subsection{Guarantee}

Social objects are guaranteed by the stability they acquire within social structures over time. There need not be any general reason for why these objects naturalise over others, or why these objects and not others are constructed to begin with-the circumstances and content of the constructions, just as the reasons for their

\footnotetext{
16 This is the other side of György Lukács' observation of the phenomenon of 'reification', wherein one's "own activity [...] becomes something objective and independent of [them], something that controls [them] by virtue of an autonomy alien to man" (Lukács 1971, p. 87). While Michael J. Thompson insightfully notes that reification [Verdinglichung] draws on Kantian distinctions between Ding, Gegenstand, and Objekt as levels of being cognised, this alone nevertheless fails to account for how ideology also concerns the Subjekt, the cognising empirical unity of apperception [empirische Einheit der Apperzeption] i.e. the interpellated subject (Thompson 2017; cf. Althusser 2005, p. 230 note 7).
} 
propagation, are of course socio-historically specific. At the same time, this feedback loop always occurs against a formal background system of other loops that occur in the broader social world and among other subjects. Hacking (2007) observes that looping also involves more than the arcs between classifications and classified at the individual level, including also, at the structural level, knowledge involving such classifications, experts who classify, and institutions that uphold classifications (Figure 2):

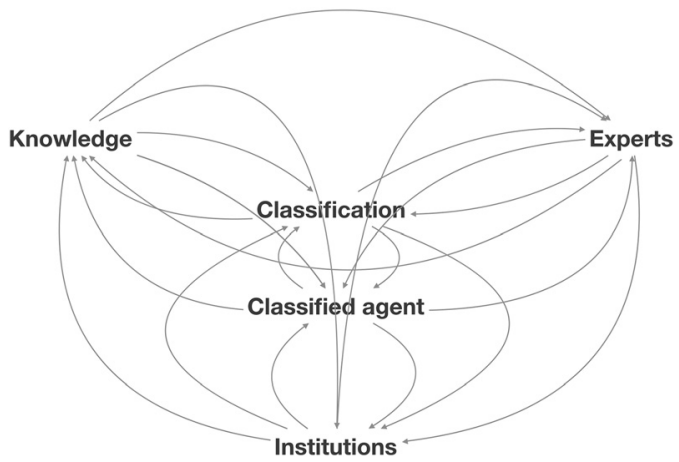

Figure 2: Looping Illustration 2

Consider, for example, how the link between disabled people and disability classifications are understood to stabilise and be stabilised by how disability is understood in medical and non-medical literatures, medical professionals and disability activists, as well as hospitals and legislative councils (Lim 2018).

Our concern here is explicitly for looping mechanisms that are epistemically unresponsive (unlike, say, epistemic virtues). Remaining pluralistic about the mechanisms, then, the following is a suggested, inexhaustive list of such mechanisms at both individual and structural levels, noting that they need not all occur and that not all of them are problematic in themselves:

Individual: Nash equilibria, stereotype threat/boost, implicit bias, wishful thinking, confidenceshaking, speech act accommodation, epistemic laziness, testimonial injustice, etc. ${ }^{17}$

Structural: market equilibration, culture industry, consumer production, hermeneutical injustice, etc. ${ }^{18}$

An example of a looping mechanism functioning at the individual level to perpetuate structural oppression as may be found in the stereotype boost for East Asians in

17 See Battaly 2014; Dotson 2014; Fricker 2007; Langton 2018; Mallon 2016; Rosen 1996; Stanley 2015.

18 See Adorno and Horkheimer 2016; Dotson 2014; Fricker 2007; Haslanger 2011. 
North America. Joint acceptance of East Asians as possessing properties of being highly competent but cold and submissive constructs the classification of the 'AsianAmerican' as a model minority and interpellates relevant individuals (Berdahl and Min 2012). This undergirds the recognition of the Asian-American-as-modelminority that manifests in practices like hiring decisions or deferring the calculation of splitting of the bill to them. With these practices, many such individuals also recognise themselves as possessing these properties due to the stereotype boost, contributing to their relative absence in leadership positions (Sy et al. 2010).

An example of a looping mechanism functioning at the structural level is found in Haslanger's example of market equilibration in the global food industry:

In a less-globalized world than ours, food crops were grown to support the local cuisine and the local tastes and culinary techniques evolved in ways that took advantage of the crops. In more complex and broadly social changes we can watch consumer taste develop so that certain products become 'must haves' in a particular milieu. Trends in cuisine can become trends in production which, in turn, affect trends in labor, and this affects schemas of class and taste, and so on.

$[\ldots]$

The reliance on, say, wheat in a particular cuisine may seem inevitable, natural, 'given'. Wheat is what is available; wheat just is what we eat. But the wheat is available because of the impact of schemas on resources that establish farming practices, food distribution, and such. Given the stability of such structures, culinary taste conforms. In this context quinoa, or soy, or spelt tastes bad and has a funny texture too; so who would want to plant it? (Haslanger 2011, p. 197-198)

This provides with a looping mechanism that stabilises, say, Orientalist attitudes towards tofu-based dishes as 'a Far East exoticism'.

Looping effects thus allow us to say that the ignorant beliefs in false consciousness both supports (functional 'falsity') and is supported by structural oppression (genetic 'falsity'), though we avoid vacuous circularity since the relevant ideological schematisations of the oppressed are constructed and naturalised for an agent over time. This also means that the formation of a given false consciousness in the agent neither is causally prior to, nor emerges simultaneously with, the relevant oppressive relation. Rather, the relevant oppressive relation exists, at least initially, independently of the interpellation and hence also prior to the development of the particular false consciousness-guaranteeing it. That is, looping mechanisms normalise, or render 'natural', existing oppressive relations. This is not to say that such oppressive relations do not also depend on false consciousness later on, only that it is impossible to exhaust the reasons for why a 
given instance of false consciousness is problematic without also attending to why the relations of its corresponding social structure(s) are problematic. ${ }^{19}$

\subsection{Dynamics}

The dependence of false consciousnesses on an oppressive relation means that they are domain-based: indexed to the range of resources and agents schematised by the relevant social structure. A given social structure would delineate a stabilised complex of loops, but a given domain may at the same time be schematised, partially or wholly, in other structures (oppressive or otherwise). Importantly, this mean that a given instance of false consciousness is limited both in its content and mechanisms. An instance pertaining to suffrage, for example, would not involve beliefs about Pluto. Being domain-based means that false consciousness might not develop, or could erode, for at least two reasons: radical marginalisation and epistemic friction.

Radical marginalisation comes from Marx's own description of the proletariat as the locus of the possibility of German emancipation: the violent revolt of the fully oppressed, who have nothing to lose but their 'radical chains', against the existing structure as a whole. It is precisely the insignificance of the structure for such agents who are completely marginalised that allows for the possibility of emancipatory consciousness. This is because the stabilising mechanisms have no force on them since they are not subjects under the domain of the ideological schemas (for example, there would be no stakes at all for confidence-shaking): they would be able to form beliefs independent of ideology.

Epistemic friction comes from the fact that different social structures may schematise over the same resources and agents. That is, an agent likely has multiple group memberships within a given society and, as such, be under multiple schemas in cases of overlapping oppression (whether purely oppressor, oppressed, or a mix). As Althusser notes:

19 This leaves open the question of the appropriate norms of evaluation, i.e. the normative problem: whether they are external, holding it to universal standards applicable to any social structure (such as critiques employing 'neutral' conceptions of justice); internal, holding it to standards that the social structure itself schematises as its standards (such as critiques on the basis of unconstitutionality); or more complex modes, like immanent or reconstructive critiques (cf. Celikates 2018; Haslanger 2017b; Jaeggi 2019). And, importantly, in cases of false consciousness in overlapping oppression: (if the norms are not external) how to critique cases that involve two different schemas. 
Ideologies never stop interpellating subjects as subjects, never stop 'recruiting' individuals who are always-already subjects. The play of ideologies is superposed, criss-crossed, contradicts itself on the same subject: the same individual always-already (several times) subject. (Althusser 2014, p. 193-194).

From this multiplicity, ideologies can either be compounded or neutralised for an agent. When they are compounded, schemas combine such that a given false consciousness can gain not only content but further stabilising mechanisms that reinforces evidence-resistance. At the same time, these overlaps can also condition the prevention or erosion of false consciousness in cases where ideologies are neutralised. For such a multiplicity of self-understandings may generate what José Medina calls 'epistemic friction', a discordance resulting from incompatible schemas and stabilising mechanisms running up against each other, which may lead to 'meta-lucidity'. An agent would thus have "insights in to the functioning of perspectives that makes it possible to redraw [one's] cognitive maps, to redescribe [one's] experiences, and to reconceptualize [one's] ways of relating to others" (Medina 2013, p. 47). Such reconceptualisation would not take place in abstracto, but rather would be responsive to the various extant self-understandings.

In both cases of a lack of development or erosion, it is by participating in alternate social constructions of objects-and oneself as a subject-in nonideological or resistant communities that one might come under social schemas stabilised by epistemically responsive mechanisms, and thus non-ideological or emancipatory knowledge. This supports the processualists' insight of resistant practices, while also accounting for how agents might avoid false consciousness in the first place.

However, such erosions-which may take a while-render emancipatory consciousness only possible and cannot guarantee actualisation. For resistant communities to be successful, alternate schemas must overcome the interpellation of the old ideologies. ${ }^{20}$ That is, to the extent of diminishing the joint acceptances that issue from the norm of acknowledging that one is interpellated by a particular ideology. For example, no one would acknowledge being hailed as a Roman citizen in Victorian Britain. Such diminishment requires sustained competition and control over the schematised resources and looping mechanisms, and may be unsustainable in the long run without disrupting looping at the structural level, as well as the corollary reconfiguration of the internal relations of the relevant social structures. The massive changes to British labour markets during the First World War and the consequent shifts in public consciousness of women's role were

20 This leaves open how representative such new schemas and communities would be, if other oppressed agents do not share the same overlaps of structural oppression (i.e. the epistemological problem), cf. Celikates 2017. 
crucial for securing suffragism's success. It is thus perhaps unsurprising that false consciousness is just as commonly, if not more often, reinforced by epistemic friction (Nyhan and Reifler 2010). Or erosion sometimes even results in a new type of false consciousness developing in moments of meta-lucidity as a flight from 'meaning vertigo' back to the interpellation of the old ideology (Melo Lopes 2019). Similarly, it remains a controversial empirical question whether a revolt by the radically marginalised has ever been or will ever be more than a possibility.

\subsection{Summary}

I will now summarise the foregoing and how social constructionism accommodates the previous three approaches. The social constructionist approach to false consciousness understands the formation and maintenance of ignorant beliefs to be grounded in agents taking a certain socially objectified understanding of themselves as natural self-understanding, within variable complexes of epistemically unresponsive looping mechanisms that are embedded in oppressive social structures over time. A given complex could overlap with another to form either a non-additive set of beliefs that includes both ideologies, or erode either sets of beliefs-this depends on the compatibility of looping mechanisms salient for the agent in question.

The social constructionist would explain the particular case of ANTISUFFRAGIST as follows:

EXPLANATion $_{\text {sc }}$ : Ward has the ignorant beliefs that women are naturally deficient at political deliberation and that suffrage is unnecessary for addressing injustices, motivating her to campaign against women's suffrage, because the contents of those beliefs are being sustained by a complex of looping mechanisms at the individual level and structural level. These mechanisms are patriarchal and bourgeois.

At the individual level, this involves a loop between Ward's self-understanding and patriarchal and bourgeois classifications: the classification of 'domestic creature' under patriarchal ideology and the classification of 'subject who is capable of activities that secure economic independence' under bourgeois ideology. These then merge as 'women are capable of national domestic interests' and is sustained by mechanisms like testimonial injustice and epistemic arrogance.

At the structural level, these would further involve an organisation of loops involving: the contemporary gender exclusion in political institutions but gender inclusion in literary institutions; the expert opinions of members of the Houses of Parliament, literary figures, and critics; and the limited public knowledge of the political capacity of women. These are sustained by mechanisms like hermeneutical injustice and market equilibrium. 
Acquisition and Content are thus met in EXPLANATION $_{S C}$ and shown to be interacting in the complex of looping mechanisms at both individual and structural levels. Scope is met in attending to how suffragists might lack similar testimonial injustice or might not have similar assurances with the 'existing constitutional machinery', thereby coming to know of women's capacity to perform activities that would but do not secure economic independence, sustained by the growing resistant community of the social movement. And lastly, Systematicity is met, since Acquisition, Content, and Scope are interconnected by the complexes of looping mechanisms in both gender and economic structures whose domains significantly overlap. And, while the general form of this explanation may be applied to cases like Simkins', the particular explanation $\left(\right.$ EXPLANATION $\left._{S C}\right)$ only extends to antisuffragists in a similar social position to Ward. The looping mechanisms pertaining to the latter involve a different overlap of gender and economic oppression to the former: the resources of upper- and middle-class British women then, like charitable funds and chambermaids, are not shared by working-class women.

Like functionalism then, social constructionism is pluralistic regarding which underlying mechanisms are at play in general: it could be one or a combination of them in a particular case of false consciousness. Instead of a specific mental state that agents are in, false consciousness is to be understood as a conceptual tool that regulates systematic social research (without predetermining the particular mechanisms for every instance). What is further provided by the social constructionist framework is a means to identify and unify these mechanisms under a given ideology or, importantly, multiple ideologies (Acquisition), as well as account for their absence (Scope).

Social constructionism also accommodates the various possible psychological mechanisms that might factor into particular cases of false consciousness, without committing itself to any one (or set) of them as essential to the concept. Moreover, it provides an account for why ideal psychological conditions are so difficult to achieve and sustain, in supplementing the psychologistic approach with Content, Scope, and Systematicity.

Finally, like processualism, social constructionism is attentive to epistemic oppression and the epistemic failure of false consciousness as relational failure. It also provides an account for the possibility of the success and failure of resistant epistemic practices. At the same time, social constructionism is also able to address cases that are not conspiratorial in origin or that do not depend on material inequality (Scope), as well as the positive internalisation of ideological selfunderstanding (Acquisition). 


\section{Conclusion}

I have argued that social constructionism is the most comprehensive answer to the explanatory problem of false consciousness. It provides a general theory that meets all four explanatory desiderata of Acquisition, Content, Scope, and Systematicity needed for the concept in social research and emancipatory praxis. And, instead of supplanting functionalism, psychologism, and processualism, it subsumes their explanatory strengths and supplements their weaknesses. This thus places us on firm footing to address the other problems of false consciousness.

\section{References}

1889. “An Appeal Against Female Suffrage." Nineteenth Century 25: 781-8.

Adorno, T. W., and M. Horkheimer (2016) Dialectic of Enlightenment. Translated by J. Cumming. London and New York: Verso.

Althusser, L. 2005. For Marx. Translated by B. Brewster. London and New York: Verso.

Althusser, L. 2014. On the Reproduction of Capitalism: Ideology and Ideological State

Apparatuses. Translated by G. M.Goshgarian. London and New York: Verso.

Arendt, H. 1976. The Origins of Totalitarianism, 2nd ed. New York: Harcourt, Inc.

Ásta 2018. Categories We Live By. New York: Oxford University Press.

Ásta 2019. “Categorical Injustice.” Journal of Social Philosophy 50 (4): 392-406.

Barnes, A. 1997. Seeing Through Self-Deception. Cambridge: Cambridge University Press.

Battaly, H. 2014. "Varieties of Epistemic Vice." In The Ethics of Belief, edited by J. Matheson, and R. Vitz, 51-76. Oxford University Press.

Berdahl, J. L., and J.-A. Min. 2012. "Prescriptive Stereotypes and Workplace Consequences for East Asians in North America." Cultural Diversity and Ethnic Minority Psychology 18 (2): 141-52.

Bloomfield, J. 2017. “3 Reasons Why Women Should Not Vote”. Women against Feminism. https:// womenagainstfeminism.com/3-reasons-why-women-should-not-vote (accessed February 15, 2020).

Bush, J. 2007. Women against the Vote: Female Antisuffragism in Britain. Oxford and New York: Oxford University Press.

Celikates, R. 2017. "Epistemische Ungerechtigkeit, Loopingeffekte und Ideologiekritik. Eine sozialphilosophische Perspektive.” West: Neue Zeitschrift für Sozialforschung 14 (2): 53-72.

Celikates, R. 2018. Critique as Social Practice: Critical Theory and Social Self-Understanding. Translated by N. van. Steenbergen. London: Rowman \& Littlefield International.

Chew, P. K. H., J. L. Young, and G. P. K. Young/Tan. 2019. "Racism and the Pinkerton Syndrome in Singapore: Effects of Race on Hiring Decisions.” Journal of Pacific Rim Psychology 13 (16), https://doi.org/10.1017/prp.2019.9.

Clark, A. 2015. Surfing Uncertainty: Prediction, Action and the Embodied Mind. New York: Oxford University Press.

Cohen, G. A. 1982. "Reply to Elster on 'Marxism, Functionalism, and Game Theory'." Theory and Society 11 (4): 483-95. 
Cohen, G. A. 2001. Karl Marx's Theory of History: A Defence, Expanded Edition. Princeton, N): Princeton University Press.

Crenshaw, K. 1991. "Mapping the Margins: Intersectionality, Identity Politics, and Violence against Women of Color." Stanford Law Review 43 (6): 1241-99.

Cudd, A. E. 2006. Analyzing Oppression. Oxford and New York: Oxford University Press.

Curry, T. J. 2014. "Michael Brown and the Need for a Genre Study of Black Male Death and Dying." Theory \& Event 17 (3).

Dotson, K. 2014. “Conceptualizing Epistemic Oppression." Social Epistemology 28 (2): 115-38.

Elster, J. L. 1982. "Belief, Bias and Ideology.” In Rationality and Relativism, edited by M. Hollis, and S. Lukes, 123-48. Cambridge, MA: The MIT Press.

Elster, J. L. 1983. Sour Grapes: Studies in the Subversion of Rationality. New York: Cambridge University Press.

Fricker, M. 2007. Epistemic Injustice: Power and the Ethics of Knowing. Oxford and New York: Oxford University Press.

Gendler, T. S. 2011. “On the Epistemic Costs of Implicit Bias.” Philosophical Studies 156 (1): 33-63.

Geuss, R. 1981. The Idea of a Critical Theory: Habermas and the Frankfurt School. Cambridge: Cambridge University Press.

Hacking, I. 1995. "The Looping Effects of Human Kinds." In Causal Cognition: A Multidisciplinary Debate, edited by D. Sperber, D., D. Premack, and A. J. Premack, 351-94. New York: Clarendon Press.

Hacking, I. 2007. “Kinds of People: Moving Targets.” Proceedings of the British Academy 151: 285-318.

Haslanger, S. 2011. "Ideology, Generics, and Common Ground.” In Feminist Metaphysics: Explorations in the Ontology of Sex, Gender and the Self, edited by C. Witt, 179-207. Dordrecht and London: Springer.

Haslanger, S. 2014. "The Normal, the Natural and the Good: Generics and Ideology." Politica \& Società 3: 365-92.

Haslanger, S. 2017a. "Racism, Ideology, and Social Movements." Res Publica 94 (1): 1-22.

Haslanger, S. 2017b. "Culture and Critique.” Aristotelian Society Supplementary 91 (1): 149-73.

Haslanger, S. 2019. “Disciplined Bodies and Ideology Critique.” Glass Bead 2 (1). visited https:// www.glass-bead.org/article/disciplined-bodies-and-ideology-critique (accessed September 22, 2019).

Hohwy, J., and J. Michael. 2017. "Why Should Any Body Have a Self?" In The Subject's Matter: SelfConsciousness and the Body, edited by F. de Vignemont, and A. J. T. Alsmith, 363-91. Cambridge, MA: MIT Press.

Hutchinson, D. 2001. “Identity Crisis: Intersectionality, Multidimensionality, and the Development of an Adequate Theory of Subordination." Michigan Journal of Race and Law 6 (2): 285-317.

Jaeggi, R. 2009. "Rethinking Ideology". Translated by E. Engels. In: New Waves in Political Philosophy, edited by B. P. de Bruin and C. F. Zurn, 63-86. New York: Palgrave-Macmillan. Jaeggi, R. 2019. Critique of Forms of Life. Translated by C.Cronin. Cambridge, MA, and London: The Belknap Press of Harvard University Press.

Jugov, T., and L. Ypi. 2019. "Structural Injustice, Epistemic Opacity, and the Responsibilities of the Oppressed." Journal of Social Philosophy 50 (1): 7-27.

Langton, R. 2018. "The Authority of Hate Speech." In Oxford Studies in the Philosophy of Law, Vol. 3, edited by J. Gardner, L. Green, and B. Leiter, 123-52. Oxford: Oxford University Press. 
Lerner, M. J. 1980. The Belief in a Just World: A Fundamental Delusion. New York: Plenum Press.

Lim, C.-M. 2018. "Disabilities Are Also Legitimately Medically Interesting Constraints on Legitimate Interests.” Mind 127 (508): 977-1002, https://doi.org/10.1093/mind/fzy028.

Lopes, F. M. 2019. "Perpetuating the Patriarchy: Misogyny and (Post-)Feminist Backlash.” Philosophical Studies 176 (9): 2517-38.

Lukács, G. 1971. "Reification and the Consciousness of the Proletariat”. In History and Class Consciousness: Studies in Marxist Dialectics. Translated by R.Livingstone, 83-222. Cambridge, MA: The MIT Press.

Mallon, R. 2016. The Construction of Social Kinds. Oxford: Oxford University Press.

Medina, J. 2013. The Epistemology of Resistance: Gender and Racial Oppression, Epistemic Injustice, and Resistant Imaginations. New York: Oxford University Press.

Meyerson, D. 1991. False Consciousness. Oxford: Clarendon Press.

Mill, J. S. 1995. "The Subjection of Women." In On Liberty, with the Subjection of Women and Chapters on Socialism, edited by S. Collini, 117-217. Cambridge: Cambridge University Press.

Mills, C. W. 2017. “Ideology.” In The Routledge Handbook of Epistemic Injustice, edited by I. J. Kidd, J.Medina, and G. Pohlhaus Jr., 100-11. London and New York: Routledge.

Nyhan, B., and J. Reifler. 2010. "When Corrections Fail: The Persistence of Political Misperceptions." Political Behavior 32 (2): 303-30.

Paprzycka, K. 1998. “Must False Consciousness Be Rationally Caused?" Philosophy of the Social Sciences 28 (1): 69-82.

Pettit, P. 1991. "Realism and Response-Dependence." Mind 100 (4): 587-626.

Pohlhaus, Jr. G. 2020. “Epistemic Agency under Oppression.” Philosophical Papers 49 (2): 233-51.

Renault, E. 2016. “Critical Theory and Processual Social Ontology.” Journal of Social Ontology 2 (1): 17-32.

Rosen, M. 1996. On Voluntary Servitude: False Consciousness and the Theory of Ideology. Cambridge: Polity Press.

Searle, J. R. 2010. Making the Social World: The Structure of Human Civilization. Oxford: Oxford University Press.

Seth, A. K., K. Suzuki, and H. D. Critchley. 2012. "An Interoceptive Predictive Coding Model of Conscious Presence.” Frontiers in Psychology 2: 395.

Shelby, T. 2003. "Ideology, Racism, and Critical Social Theory." The Philosophical Forum 34 (2): 153-88.

Shelby, T. 2014. “Racism, Moralism, and Social Criticism.” Du Bois Review 11 (1): 57-74.

Simkins, M. E. 1909a. “The Working Woman's Plea for Exemption from Political Responsibility.” In An Englishwoman's Home, 3-28. London: Sampson Low, Marston \& Co. Limited.

Simkins, M. E. 1909b. "Suffrage and Antisuffrage - A Woman Worker's Appeal." The National Review 784-93.

Stanley, J. 2015. How Propaganda Works. Princeton and Oxford: Princeton University Press.

Srinivasan, A. 2016. "Philosophy and Ideology." Theoria 31 (3): 371-80.

Sy, T., L. M. Shore, J. Strauss, T. H. Shore, S. Tram, P. Whiteley, and K. Ikeda-Muromachi. 2010. "Leadership Perceptions as a Function of Race-Occupation Fit: The Case of Asian Americans." Journal of Applied Psychology 95 (5): 902-19.

Thompson, M. J. 2013. “A Functionalist Theory of Social Domination." Journal of Political Philosophy 6 (2): 179-99. 
Thompson, M. J. 2017. “Collective Intentionality, Social Domination, and Reification.” Journal of Social Ontology 3 (2): 207-29.

Ward, M. A. 1918. "Let Women Say! An Appeal to the House of Lords." Nineteenth Century and After 83: 47-59. 